International Journal of Discrimination and the Lar, 2005, Vol. 7. pp. 127-168

$1358-2291 / 2005 \$ 10$

c. 2005 A B Academic Publishers. Printed in Great Britain

\title{
NEGOTIATING RESPECT: SEXUAL HARASSMENT AND THE LAW IN HONG KONG
}

\author{
CAROLE J. PETERSEN* \\ Faculty of Law, University of Hong Kong
}

\begin{abstract}
This article critiques the sexual harassment provisions of Hong Kong's Sex Discrimination Ordinance, as well as the enforcement model. Although the judiciary has had some opportunity to interpret the Ordinance, most complaints never reach the courts because the Equal Opportunities Commission has a statutory duty to attempt to conciliate a complaint before granting legal assistance. When the Ordinance was enacted it was widely assumed that Chinese women would prefer confidential conciliation to a public hearing. However, interviews with past complainants and representatives of women's organizations reveal that many complainants find conciliation conferences to be extremely stressful. They also feel demeaned and disempowered by what is effectively an obligation to negotiate with the respondent. The author concludes that the current model exacerbates the power imbalance between complainants and respondents and limits the systemic impact of the law. She argues that an informal and inexpensive Equal Opportunities Tribunal should be created. This would allow those complainants who are willing to try their complaints to proceed directly to a hearing, without any obligation to first participate in conciliation.
\end{abstract}

\section{INTRODUCTION}

This article critiques Hong Kong's law of sexual harassment and its enforcement model, which encourages conciliation of complaints. In addition to the statutory provisions and a small number of litigated cases, the article also draws upon a random sample of complaints filed with the Hong Kong Equal Opportunities Commission and interviews with individuals who have participated in the conciliation process at the Commission. Sexual harassment now represents the second largest category of complaints filed under the Sex Discrimination Ordinance ${ }^{1}$ and the sexual harassment complaints in our sample had a reasonably high rate of conciliation (nearly $55 \%$ ). Nonetheless, interviews with a selection of past complainants and women's organizations reveal significant dissatisfaction with the current model. They report that complainants often resent being asked to negotiate with their harasser, feel powerless during the conciliation conference, 
and are disappointed to find that there is no judgment at the end of the process. These results are surprising since it was widely assumed, when the legislation was enacted, that Hong Kong women would prefer conciliation to a hearing.

The second part of the article briefly reviews the legislative history of Hong Kong's Sex Discrimination Ordinance ${ }^{2}$ and the enforcement model. The third part considers the scope of the sexual harassment provisions, including the areas in which sexual harassment is prohibited, vicarious liability of employers, and liability for victimization. The fourth part analyses the definition of sexual harassment under the Ordinance, which is somewhat different for harassment in the workplace than for harassment in other areas. The fifth part discusses the case of Yuen Sha Shav. Tse Chi Pan, ${ }^{3}$ in which a university student was held liable for sexual harassment after he secretly videotaped another student as she undressed. This was the first sexual harassment case to be tried in Hong Kong and established an important precedent. Indeed, it is one of the few reported cases, in any jurisdiction, based entirely upon an invasion of the victim's privacy. The sixth part discusses remedies for sexual harassment, including compensatory damages, exemplary damages, and orders to apologize, the legality of which has been upheld by Hong Kong's Court of Final Appeal, albeit only in rare cases. The seventh part analyses the use of conciliation and the role of the Equal Opportunities Commission in sexual harassment complaints. This section relies upon a random sample of complaint files and interviews with staff at the Commission, past complainants, representatives of women's support groups, and others who have participated in the complaints process. I conclude that the existing model leaves too much power in the hands of respondents and limits the systemic impact of the law. I suggest that an informal equal opportunities tribunal be established for those complainants who are willing to take their complaints to a hearing.

\section{LEGISLATIVE HISTORY AND HONG KONG'S ENFORCEMENT MODEL}

Prior to 1991, the concept of equality was almost entirely absent from Hong Kong's legal system. ${ }^{4}$ The British government ratified the Convention on the Elimination of All Forms of Discrimination Against Women (CEDAW) in 1986. However, it departed from its normal practice of extending human rights treaties to its dependent territories and chose not to extend CEDAW to Hong Kong. ${ }^{5}$ This decision was apparently made at the request of the Hong Kong government, which maintained many discriminatory laws and policies at that time. Certain other international human rights 
conventions that applied to Hong Kong included the right to equality but they were not enforceable as domestic law in the Hong Kong courts. As a result, sex discrimination was openly practised and accepted as the norm. For example, women were legally barred from inheriting much of the land in the New Territories part of Hong Kong and virtually every newspaper contained sex-specific job advertisements. ${ }^{6}$ Women's organizations regularly lobbied for law reform. However, the legislative process was largely controlled by the government and the business community, which firmly opposed anti-discrimination laws.

Fortunately, in the transition period leading to 1997, Hong Kong underwent significant legal and political developments. ${ }^{7}$ In late 1989 (as part of its efforts to rebuild public confidence after the Beijing massacre), the Hong Kong government proposed a Bill of Rights for Hong Kong. Enacted in 1991, the Bill of Rights Ordinance was the first domestic law to recognise a right to gender equality and women's organizations used its enactment to publicise gender issues and educate legislators. This was significant as the government was also introducing limited democracy reforms and the legislature was becoming more accountable to the public. Several legislators became strong supporters of the equality movement. Pressure from these legislators ultimately compelled the government to conduct its first public consultation on sex discrimination, which revealed widespread public support for the enactment of sex discrimination legislation and the extension of CEDAW to Hong Kong.

One legislator, Ms Anna $\mathrm{Wu}$, put further pressure on the government by drafting her own Equal Opportunities Bill ${ }^{8}$ which sought to prohibit discrimination on a wide range of grounds (including sex, disability, sexuality, race, and age), as well as sexual harassment. Initially the government ignored her bill, dismissing it as too radical to be taken seriously. However, in early $1994 \mathrm{Wu}$ distributed her draft bill for public comment and a significant number of fellow legislators pledged to support it. In July 1994 she formally introduced her bill into the Legislative Council and a Bills Committee began to study it. At this point the government realised that it had little choice but to abandon its opposition to the concept of antidiscrimination legislation. The legislature was due to become fully elected in 1995 and even pro-business legislators would thus find it difficult to oppose Wu's bill, unless they could be presented with a more conservative alternative. The government thus reluctantly announced that it would soon introduce its own Sex Discrimination Bill and Disability Discrimination Bill. These two areas of discrimination had attracted the most public concern and the government hoped that by promising to legislate against them it could prevent Wu's broader bill from being enacted. 
At first, there was some dispute about whether the government's Sex Discrimination Bill would expressly prohibit sexual harassment. The Secretary for Home Affairs initially announced that it would not do so. He probably assumed this because he knew that the government planned largely to copy the UK Sex Discrimination Act 1975 (which, as originally enacted, did not expressly address sexual harassment although it was interpreted by the courts to prohibit it where it constitutes unlawful discrimination). ${ }^{9}$ However, women's organizations reacted very negatively to this announcement and the government subsequently confirmed that it would add provisions expressly defining and prohibiting sexual harassment, which it borrowed from the Australian federal Sex Discrimination Act 1984 (as amended in 1992). ${ }^{10}$

Although the government's bill was narrower and more conservative than Wu's Equal Opportunities Bill, most women's organizations (and ultimately $\mathrm{Wu}$ herself) supported it, largely because the government had the constitutional power to create an Equal Opportunities Commission. ${ }^{11}$ However, Wu and women's organizations proposed numerous amendments to strengthen the government's bill. One of these amendments expanded the definition of sexual harassment in employment-related cases and is discussed below. ${ }^{12}$

When the various discrimination bills were being considered by the legislature there was substantial debate on the enforcement model that should be adopted. From the start, it was suggested that a model that emphasised conciliation would be appropriate for Hong Kong's cultural and economic context. Indeed, one labour expert suggested that Hong Kong should follow the example of Japan, where the employment discrimination legislation initially lacked any effective enforcement mechanism and relied instead upon persuasion. He argued that:

"[The Japanese] Act has won approval as a vehicle of 'gradualistic' reform for being able to signal to the public, especially the business community, the moral importance of vindicating the rights of women at the workplace, while remaining prudent enough to recognise traditionally enshrined customs and practice, both in family and society. In Hong Kong, there is no reason why similar prudence at the normative level should not be exhibited, given our Confucian heritage. While the present enthusiasm for human rights should not stop at the factory gate, it is equally important that the assiduous propagation of these standards and values should not undermine or attempt to supplant Chinese family values and traditions among those for whom they are a cherished legacy."13

There is no question that Hong Kong employers would have supported this approach. However, women's organizations were 
aware of the limited impact of the Japanese law and they had already expressed their opposition to a similar proposal based upon persuasion (which had been raised by the government in the 1993 Green Paper on Equal Opportunities for Men and Women). ${ }^{14}$ The women's movement had also gained considerable support in the legislature. Thus, by the 1994-95 legislative session, the Hong Kong government knew that it had to propose something stronger than moral persuasion if it was to serve as a viable alternative to Anna Wu's Bill. It therefore agreed that the Sex Discrimination Bill and Disability Discrimination Bill would be enforceable in the courts, with investigation and conciliation services provided by an Equal Opportunities Commission. However, the government declined to create a specialist equal opportunities tribunal, which had been an element of Anna Wu's proposals. ${ }^{15}$

The result was a compromise model, but one that has the effect of discouraging litigation. Victims of discrimination and harassment may, if they wish, file a complaint directly in the District Court. However, most victims of discrimination cannot afford to do so, as Hong Kong has notoriously high legal fees and contingency fee arrangements are not permitted. Instead, most complainants rely entirely upon the free assistance provided by the Commission. The legislation obligates the Commission to investigate and 'endeavour to conciliate' all complaints filed with it (except for those that lack substance or can be discontinued on other grounds provided by the statute). Thus, although there is no statutory requirement that a victim of sexual harassment attempt to conciliate her complaint, in practice she is compelled to participate in conciliation as long as the respondent is willing to do so. If the complainant refuses to participate (or rejects what the Commission believes is a reasonable offer), it is unlikely that the Commission will later grant her assistance to litigate.

The next two sections consider the scope of liability and the definition of sexual harassment under Hong Kong law.

\section{THE SCOPE OF LIABILITY FOR SEXUAL HARASSMENT}

\section{The Protected Spheres}

Like most jurisdictions, Hong Kong only prohibits sexual harassment in certain protected spheres, which are defined in sections 23, 24, 39, and 40 of the Sex Discrimination Ordinance. Section 23 addresses harassment in the workplace and is drafted quite broadly. It protects employees, employers, applicants for jobs, contract workers and commission agents. It is also unlawful for a partner in 
a firm to harass another partner or someone seeking to become a partner (section 23(6)). The Ordinance expressly applies to persons who are proposing to form a partnership, as well as to existing firms (section 23(7)).

Section 23 also provides a special provision for domestic helpers. There are a large number of foreign domestic helpers in Hong Kong and they are particularly vulnerable to sexual harassment, as they generally live with their employers and risk deportation if they are fired. The standard provisions prohibiting sexual harassment by an employer or co-worker would not provide adequate protection, as the 'employer' of a domestic helper is the person who signs her contract, whereas she may be sexually harassed by others who reside in the household (such as the husband or the son of the employer). Section 23(12) thus provides that it is unlawful for 'any person who resides on the premises' to harass a domestic helper who works there. Of course, in practice, it is difficult for a foreign domestic helper to file a complaint of sexual harassment, as she would almost certainly have to leave her employer's residence and would find it difficult to remain in Hong Kong to pursue her claim. Nonetheless, some domestic helpers have filed sexual harassment complaints with the Commission, as well as criminal complaints.

Section 24 extends the prohibition on sexual harassment to four additional areas that are related to work. It applies to: trade unions (it is unlawful for a member to sexually harass another member or someone seeking to become a member); qualifying bodies (it is unlawful for a member of a qualifying body, such as the Law Society, to sexually harass a person who is seeking an authorization or qualification); and providers of employment-related training. It is also unlawful for a person who operates or works for an employment agency to sexually harass a person in the course of providing or offering to provide the agency's services.

Apart from employment, education is probably the sphere in which women are most likely to experience sexual harassment. Section 39 protects students and potential students from harassment, not only by staff but also by other students. (The first sexual harassment case to be tried in Hong Kong, discussed below, concerned student-to-student sexual harassment, a problem which has received significant public attention in recent years.) Teaching staff are also protected from harassment by students and potential students. (If a member of staff is harassed by a co-worker, that would fall within section 23, harassment in employment.)

Section 40 defines the remainder of the 'protected spheres' (those that do not fall within the areas of work or education). It applies to the provision of goods, facilities and services, a broad 
category which would include the provision of medical care, legal services, sports facilities, retail goods, and transportation. Section 40 also makes it unlawful for a person who manages premises to sexually harass a person in the course of managing, providing, or offering to provide premises to her. Finally, section 40 includes a special provision for barristers because a barrister works as a solo practitioner and is not in an employment or partnership relationship with other members of chambers. Section 40(6)-(7) makes it unlawful for a barrister or barrister's clerk to sexually harass a barrister or pupil in chambers or to sexually harass a person in the course of offering to provide pupillage or tenancy in chambers. It is also unlawful for any person to sexually harass a barrister in the course of giving or withholding instructions.

\section{Harassment of Men and 'Same-Sex' Harassment}

Although I have tried to summarize sections 23, 24, 39, and 40 in gender-neutral language, the statute actually uses the phrase it is unlawful for a person... to sexually harass a woman', making no reference to sexual harassment of men. Similarly, the definition of sexual harassment (discussed below) refers to sexual harassment against a woman. However, tucked away in the interpretation clause is section 2(8), which states that: '[a] provision of Part III or IV framed with reference to sexual harassment of women shall be treated as applying equally to the treatment of men' and that the relevant provisions must be interpreted by the court 'with such modifications as are necessary'. Women's organizations did ask the government to use gender-neutral language throughout the Ordinance but the government refused to do so. The government's approach has created some unnecessary confusion, as section 2(8) has no heading in the table of contents and can easily be missed by a lay person.

The Ordinance does not expressly state whether 'same-sex harassment' (female-to-female or male-to-male) is prohibited. However, in my view, it is clearly covered by the law. Sections $23,24,39$ and 40 do not state that it is unlawful for a man to sexually harass a woman, but rather that it is unlawful for a person to sexually harass a woman. The explicit use of the gender-neutral term 'person' expresses a clear intention to include sexual harassment of a woman by another woman. And, in a case in which a man alleged sexual harassment by another man, the judge would be required by section 2(8) (discussed above) to give a similarly broad interpretation of the law when it is applied to male complainants. The definition of sexual harassment (discussed below) does not require that the alleged 
harasser acted out of sexual desire. It follows that a claim of "samesex' sexual harassment would not necessarily be limited to cases in which the harasser was gay or lesbian. It could also extend to situations in which homophobic co-workers repeatedly taunt a gay employee with lewd comments about his sexual life. ${ }^{16}$ Thus, although there is still no law in Hong Kong prohibiting sexuality discrimination, ${ }^{17}$ the law of sexual harassment could be used to prohibit certain types of sexuality harassment.

\section{Vicarious Liability for Sexual Harassment}

Section 46(1) of the Sex Discrimination Ordinance states that 'a]nything done by a person in the course of his employment shall be treated for the purposes of this Ordinance as done by his employer as well as by him, whether or not it was done with the employer's knowledge or approval.' Thus the Ordinance imposes vicarious liability on the employer for unlawful acts done by employees in the course of their employment. ${ }^{18}$ (Principals are also vicariously liable for unlawful acts of agents done with authority.) However, the employer can raise the defence that it took 'such steps as were reasonably practicable' to prevent his employee or agent from committing the unlawful act. The burden of proof will be on the employer to establish this defence. ${ }^{19}$

The Sex Discrimination Ordinance Code of Practice on Employment provides (at paragraph 20) quite detailed recommendations on what employers should do to prevent and address harassment. For example, it provides that employers should establish a clear policy against sexual harassment, including examples of the kind of conduct that must be avoided. The employer should then actively promote the policy, through notices, staff meetings, and training courses. The employer should also designate a co-ordinator (preferably one who is sensitive and trained in the field) to receive complaints. The complaints procedures must assure potential victims that they will not suffer any retaliation if they make complaints. Although the Code of Practice does not have the same status as the Ordinance (and does not create any additional legal duties) it may be admissible in evidence and taken into account by the court if it is relevant to a question. ${ }^{20}$ Clearly, a court could consider the fact that an employer failed to follow the Code (which has now been well publicized by the Equal Opportunities Commission) as relevant to the question of whether the employer had taken reasonable steps to prevent unlawful acts by employees.

A case litigated in 2000 demonstrates how an employer can protect itself from vicarious liability if it adopts and enforces a 
policy against sexual harassment. A male former employee of IBM (HK) Ltd. ('IBM') alleged that he had been sexually harassed by a female project manager and dismissed by the company after he complained about the harassment. The female project manager admitted that she and the plaintiff had had a personal relationship but testified that it was consensual and that she had no influence over his career (as she occupied a lower rank than the plaintiff in the management hierarchy). The case largely turned on the facts, as the Judge found the plaintiff to be an unreliable witness, rejected most of his evidence, and decided that the sexual advances of his co-worker were not unwelcome. However, the Judge also found that even if the plaintiff had been successful against his co-worker, IBM would not have been vicariously liable for her acts because it had taken reasonable steps to prevent sexual harassment and thus could establish the affirmative defense in section 46(3) of the Sex Discrimination Ordinance.

In particular, the Judge noted that IBM provided guidelines on sexual harassment and required employees to sign a certificate declaring that they had read and understood them. A supervisor had also lectured the plaintiff about an email he had sent to the first defendant (in which he had referred to her as 'Tamara Baby') that might have been interpreted as violating the policy. The Judge thus found that IBM's managers had demonstrated that they were 'ready and prepared to implement the guidelines, [and] that they were cautious in dealing with any conduct which might have a sexual harassment related overtone, in order to demonstrate their zero tolerance' of sexual harassment. ${ }^{21}$ The Judge's decision should encourage Hong Kong employers to adopt and enforce policies against sexual harassment. Although such policies obviously cannot prevent personal relationships among employees, they may protect the employer from vicarious liability in the event that such a relationship leads to a complaint of sexual harassment.

While there would appear to be no public policy impediment under Hong Kong law to insuring against liability for sexual harassment, no companies appear to be underwriting it. This may be because of the newness of sexual harassment legislation and also because damages awards have so far been so low that insurance is not generally considered to be necessary.

\section{Victimization of Complainants}

Section 9 of the Sex Discrimination Ordinance prohibits discrimination by way of victimizing a person who has sought to enforce the Ordinance or has alleged that an act that would be unlawful under the Ordinance has been committed. Section 9 also protects anyone 
who gives evidence or information in connection with proceedings under the Ordinance. There is a very real risk that a person who files or substantiates a complaint of sexual harassment will be victimized in some way, either by the alleged harasser or by coworkers. Obviously, firing the complainant would constitute less favourable treatment. Other examples would include transferring her to a less desirable position; denying her a promotion or raise to which she would otherwise have been entitled; subjecting her to undue criticism; giving her an unusually heavy workload; or putting negative comments on her personal file. A recent Hong Kong case against an international company (brought by a woman whose underlying complaint was for pregnancy discrimination) demonstrates that even large organizations with sophisticated human resource policies can make the mistake of victimizing a complainant. ${ }^{22} \mathrm{~A}$ complaint for victimization can be successful even though the underlying complaint for sexual harassment was not successful. However, the duty not to discriminate against a person who makes an allegation does not apply if the allegation turns out to be 'false and not made in good faith'.23

The vicarious liability provision discussed above (section 46) applies equally to discrimination by way of victimization. Thus, the employer must not only refrain from discriminating against the complainant, but must also prevent the alleged harasser (or other co-workers) from retaliating against her. In practice, this may be quite difficult. However if the employer can demonstrate that it took reasonable steps to protect her (for example, by directing the alleged harasser not to retaliate, giving the victim the opportunity to work with other people, and encouraging the victim to report any acts of retaliation), the employer may be able to successfully assert the defence to vicarious liability provided in section 46(3).

In the recent case against IBM (discussed above), the plaintiff alleged victimization, claiming that he was fired after he made the complaint of sexual harassment against his co-worker. However, the Judge accepted the testimony of IBM's witnesses, which was that the plaintiff was terminated for reasons unrelated to his complaint of sexual harassment, including unauthorised purchases, difficulties working with others, and a record of poor performance reviews. The Judge's summary of the testimony indicates that there was ample evidence to support this finding. ${ }^{24}$

However, the Judge also found that the plaintiff could not possibly have been dismissed as a result of his allegation of sexual harassment because the plaintiff did not make any complaint until his exit interview. ${ }^{25}$ In my view, this particular finding reflects an overly technical view of what it means to 'complain' about sexual harassment. Although the Judge rejected most of the testimony of 
the plaintiff, even the testimony of the IBM witness indicates that the plaintiff had made an allegation before his dismissal that could amount to sexual harassment if substantiated. The Judge summarized the testimony of the IBM supervisor (who later made the decision to dismiss the plaintiff) as follows:

"On 25th November [the IBM supervisor] received an email from Dl complaining about the plaintiff's P's uncooperative work attitude. He spoke to the plaintiff, who in turn showed him some emails between him and D1 which he thought were of a personal nature and that they were having an affair of some sort. The plaintiff also remarked [that] he thought that D1 was out to get him. [The supervisor] met up with the plaintiff after work... and he said that the plaintiff confided in him that he had an affair with Dl but he wanted to break it off because his girlfriend had found out about it. [The supervisor] suggested it would be best for the plaintiff to sign off from the CPA project to avoid interaction with D1 and the plaintiff chose to write a note to inform other team members of his change in responsibility." 26

The supervisor also admitted that after this meeting (but prior to the plaintiff's dismissal) the plaintiff had shown him further emails that he had received from D1, but testified that 'he [the supervisor] thought it was just their own personal matters which they would have to sort out themselves. ${ }^{27}$ A few weeks later, this same supervisor dismissed the plaintiff, at which point the plaintiff blamed his poor performance on sexual harassment. The position taken by IBM was that this exit interview was the first time that the plaintiff had complained of sexual harassment - a position that the Judge expressly accepted in her findings. In my view, this part of the judgement is questionable. Although the plaintiff apparently did not use the words 'sexual harassment' in his November meeting with the supervisor, it appears that he did express the view that Ms Russ was 'out to get him' because he wanted to end their affair. If his claim were true, it might well constitute unlawful sexual harassment - even if the affair had initially been consensual. It should be noted that section 9 of the Ordinance (which prohibits discrimination by way of victimization) does not simply protect people who make formal complaints of unlawful acts. It also expressly protects anyone who alleges acts that could 'amount to a contravention' of the Ordinance. Thus, in my view, it was incorrect for the Judge to conclude that the plaintiff never made an allegation prior to his exit interview that could fall within the scope of section 9. It would have been better if the Judge had relied entirely on her finding that IBM's decision to fire him was for cause and was not influenced by the plaintiff's complaints about Ms Russ' behaviour towards him. 


\section{THE DEFINITION OF SEXUAL HARASSMENT}

The definition of sexual harassment is contained in section 2(5) of the Sex Discrimination Ordinance. It provides three alternative definitions of sexual harassment, two of which can be applied to any case of sexual harassment and one which can be applied only in the context of work-related harassment. Section 2(5)(a) (which can be applied to any case of sexual harassment covered by the Ordinance) provides two alternative definitions of harassment. It states that:

For the purposes of this Ordinance, a person (howsoever described) sexually harasses a woman if-

(a) the person-

(i) makes an unwelcome sexual advance, or an unwelcome request for sexual favours, to her;

or

(ii) engages in other unwelcome conduct of a sexual nature in relation to her, in circumstances in which a reasonable person, having regard to all the circumstances, would have anticipated that she would be offended, humiliated or intimidated...

Section 2(7) expressly states that 'conduct of a sexual nature' includes "making a statement of a sexual nature to a woman, or in her presence, whether the statement is made orally or in writing.' Thus, telling offensive jokes to a woman or sending her offensive pornography could constitute sexual harassment, providing that it is unwelcome and a reasonable person would have anticipated that it would offend her.

Section 2(5)(b) goes on to state a third, alternative definition, which can be applied to work-related harassment (covered by sections 23 and 24), but not to harassment falling within section 39 (education) and section 40 (other spheres). ${ }^{28}$ Section 2(5)(b) states that a person sexually harasses a woman if "the person, alone or together with other persons, engages in conduct of a sexual nature which creates a sexually hostile or intimidating work environment for her.'

At first glance, it might appear that section 2(5)(a) is meant to prohibit only what the literature commonly refers to as quid pro quo harassment, since section 2(5)(b) expressly refers to hostile work environment harassment. In fact, section 2(5)(a) is not confined to quid pro quo harassment. This can be seen from an analysis of the comparable Australian provision, on which section 2(5)(a) is based. The Australian federal Sex Discrimination Act 1984 originally provided that unlawful sexual harassment only occurred where the complainant either: (1) objected to the conduct and suffered a detriment 
in connection with her employment; or (2) reasonably feared a detriment if she objected to it. ${ }^{29}$ However, in 1992, the Australian federal Sex Discrimination Act was amended so as to remove the 'detriment' requirement. Section 28 was repealed and a new section $28 \mathrm{~A}$ was added. ${ }^{30}$ As a result of this amendment, the Australian federal legislation became significantly broader. Section 2(5)(a) of the Hong Kong Sex Discrimination Ordinance (which applies to all of the protected spheres), was copied from the amended section $28 \mathrm{~A}$ of the Australian federal legislation and can similarly be applied to both quid pro quo harassment and 'hostile environment' harassment, provided that the plaintiff alleges facts which satisfy the statutory definition. ${ }^{31}$

What then is the purpose of section 2(5)(b), which expressly refers to 'hostile work environment' harassment? The answer lies in the legislative history of Hong Kong's Sex Discrimination Ordinance. The Bills Committee simultaneously studied two bills, Anna Wu's Equal Opportunities Bill and the Government's Sex Discrimination Bill. After Wu decided to support the government's bill, many women's organizations expressed concern about the words 'in relation to', which appear in section 2(5)(a)(ii) of the definition of sexual harassment. They feared that Hong Kong courts might interpret this phrase too narrowly, so as to require that the unwelcome sexual conduct was directed specifically at the victim. This could be problematic in cases in which the unwelcome conduct was not directed at a particular person, but rather was simply a part of the general working atmosphere. For example, sexual jokes may be told at staff meetings or obscene pictures may be displayed in the coffee room. In such cases, the defendant might argue that since the unwelcome conduct was not directed just at her but rather was experienced by everyone, it was not in relation to her'.

In response to these concerns, the government agreed to amend its definition of sexual harassment so as to incorporate a portion of the definition used in Wu's bill (which had been borrowed from the Western Australian Equal Opportunity Act 1984). This was the source of section $2(5)(\mathrm{b})$, which provides an additional alternative definition of sexual harassment in employment situations. It states that a person also sexually harasses a woman if the person, alone or together with other persons, engages in conduct of a sexual nature which creates a sexually hostile or intimidating work environment for her'. This provision does not require that the sexual conduct be 'in relation to' the victim but can only be applied in the context of work. Women in other spheres, such as education, may also bring an action for 'hostile environment' harassment, but they must prove that the conduct that created the hostile environment satisfied the 
definition in section $2(5)(a)$, including the requirement that the conduct was 'in relation to the victim'.

The phrase 'in relation to' has been considered by the Hong Kong Court of Appeal in an action for judicial review of a decision that a police officer should be compulsorily retired for violating a Police Headquarters Order that included the same definition of sexual harassment as section 2(5)(a) of the Sex Discrimination Ordinance. While the police officer's application for judicial review was successful, both the Court of First Instance and the Court of Appeal rejected the applicant's argument that the requirement in relation to' should be interpreted so as to exclude sexual comments that were made to a woman but were not actually about her. The Court of Appeal noted that section 2(5)(a)(ii) "covers unwelcome conduct of a sexual nature engaged in by a person in relation to the complainant although the conduct, as in this case a conversation, was not 'in respect of' her but 'with her', .32 The Court expressly stated that if a man tells sexual stories to a woman this could constitute sexual conduct 'in relation to her' for the purposes of the definition of sexual harassment.

This indicates that the Hong Kong courts are unlikely to adopt an unduly narrow interpretation of the 'in relation to' requirement. Thus, the scope of protection against sexual harassment in nonemployment areas may not be that much different from that provided in the workplace. The one problematic situation could be the general display of pornography. While this could easily be held to constitute 'hostile environment' harassment in the workplace (section 2(5)(b)), it is still unclear whether it would satisfy the definition in section 2(5)(a). If not, then the general display of pornography in a non-work environment (such as a students' lounge) might not be actionable. ${ }^{33}$ However, the Court of Appeal's decision in Ratcliffe makes it very clear that pornographic material that is communicated to particular students can constitute sexual conduct in relation to' them.

Indeed, such a case has already arisen in Hong Kong. In 1999, the XX Group, a feminist student group at the University of Hong Kong, received a series of sexually threatening emails. Explicit pornographic material was attached to the email messages and the final message included a death threat. Ultimately, the sender of the emails (a first-year male student) was identified. He was convicted of criminal intimidation and also expelled from the University for violating its sexual harassment policy. ${ }^{34}$ The main victim also filed a complaint of sexual harassment with the Equal Opportunities Commission. The respondent wisely agreed to conciliate the matter, thus avoiding the additional publicity of a civil trial. Had the case gone to trial the court likely would have held that both 
the email messages and also the pornographic material attached to the messages were 'in relation to' the woman who received them.

The next section discusses another case of 'student-to-student' harassment, one that did proceed to trial and established that voyeuristic behaviour can constitute sexual harassment under Hong Kong law.

\section{VOYEURISM AS SEXUAL HARASSMENT: THE CASE OF YUEN SHA SHA V. TSE CHI PAN ${ }^{35}$}

In March 1997, a female student at the Chinese University of Hong Kong, accidentally discovered a camcorder hidden inside a paper box on top of her roommate's wardrobe. The camcorder contained a working videotape and was pointed toward the plaintiff's bed and wardrobe, where she normally changed clothes. She also found some books beneath the camcorder, one of which bore the name of the defendant, the boyfriend of her roommate. The plaintiff confronted the defendant, and he admitted that he had been filming her over a period of several months. The videotape showed the plaintiff in various states of undress. One scene also showed the defendant adjusting the angle of the camcorder in front of the plaintiff's wardrobe and pointing at the lens, indicating that he had deliberately targeted her dressing area.

Although there was very little dispute over the facts, the defendant refused to conciliate the matter. At the trial the defendant did not give evidence or call any witnesses, and on the second day of the hearing his counsel indicated that he largely admitted liability. ${ }^{36}$ As a result, the judge apparently decided that it was not necessary to give a detailed analysis of liability and her decision is quite brief on this point. This is unfortunate, not only because the case was the first complaint of sexual harassment to be tried in Hong Kong, but also because there are very few reported decisions in any jurisdiction on this type of sexual harassment. Thus it would have been appropriate to consider precisely how the defendant's actions satisfied the statutory definition of unlawful harassment.

As the defendant did not make sexual advances to the plaintiff, section 2(5)(a)(ii) (quoted in Part 4 above) is the relevant definition. It can be divided into four elements: 1) unwelcome conduct; 2) of a sexual nature; 3) in relation to the plaintiff; and 4) which is such that a reasonable person would anticipate that the plaintiff would be offended, humiliated or intimidated. The first and third elements are not problematic. The filming was obviously 'unwelcome' as the defendant filmed the plaintiff without her knowledge and did not allege that she did anything to invite or solicit his behaviour. ${ }^{37}$ The 
'in relation to' requirement was also easily satisfied, as the defendant deliberately filmed the plaintiff. However, the other two elements conduct of a 'sexual nature' and the reasonable person test - require more detailed analysis, and I would suggest the following.

Conduct of a sexual nature: The act of filming a person is not, per se, a sexual act. In this particular case, the plaintiff testified that when she confronted the defendant he told her that he had filmed her because he was secretly in love with her and sexually attracted to her. ${ }^{38}$ However, the court noted that the defendant may well have falsely declared love for the plaintiff (in an effort to 'get off the hook') and that he may have simply filmed the plaintiff for entertainment. ${ }^{39}$ Thus it appears that the court did not consider the alleged sexual attraction as necessary to the finding that the defendant committed conduct of a sexual nature. This approach is correct, as neither the Ordinance nor the relevant case law from other jurisdictions requires a plaintiff to show that the harasser acted out of sexual desire. ${ }^{40}$ What matters is the nature of the conduct itself. While filming a person is not, per se, a sexual act, "conduct of a sexual nature' should include secretly filming a woman while she undresses. Society has long recognised the sexual connotations of viewing a woman's body without her consent. For example, in criminal law, the removal of a woman's clothing without consent (or some other legal justification) constitutes an indecent assault and therefore is classified as a sexual offence. This is true, regardless of whether the defendant acted out of sexual desire, a desire to humiliate her, or simply a desire to steal her clothing. ${ }^{41}$ What is significant is that 'right thinking people' would consider the act to be 'an affront to the sexual modesty of a woman'. ${ }^{42}$

In the context of sexual harassment, courts in other jurisdictions have also recognised that certain acts have inherent sexual connotations, irrespective of the harasser's motive. Sending or displaying graphic pornography to a woman; ${ }^{43}$ asking her explicit questions about her sexual life, ${ }^{44}$ or making insulting sexual comments about her body; ${ }^{45}$ all fall within the category of "conduct of a sexual nature'. Provided that the other elements of the definition are also satisfied, such acts constitute sexual harassment, regardless of whether the defendant sought sexual gratification. This is an important principle, as harassers often do not act out of sexual desire but rather out of a desire simply to hurt or humiliate the victim. For example, in the UK case of Insitu Cleaning Co Ltd. v. Heads, the defendant made insulting comments (such as 'Hiya, big tits') to the plaintiff at work. The defendant was much younger than the plaintiff and there was no indication that he was sexually attracted to her. The defendant thus attempted to argue that his remarks were not 'sex related', but rather were the equivalent of commenting upon a 
man's balding head. The UK Employment Appeal Tribunal rejected this argument, noting that 'a remark by a man about a woman's breasts cannot sensibly be equated with a remark by a woman about a bald head or a beard. One is sexual, the other is not. ${ }^{46}$ Similarly, in Yuen Sha Sha, the secret filming of the plaintiff while she undressed cannot sensibly be equated with other non-sexual invasions of privacy (such as tapping one's telephone line). While both activities are to be deplored, the former is sexual in nature, is a clear affront to the plaintiff's sexual modesty, and is properly addressed as a form of sexual harassment.

The reasonable person test: the final requirement is that a reasonable person would have anticipated that the plaintiff would have been offended, intimidated, or humiliated. This is often controversial and there is an ongoing debate in the literature on the question of how the hypothetical reasonable person should be defined ${ }^{47}$ However, in this case, it is difficult to see how any reasonable person (male or female) could fail to anticipate that the average woman would be offended, humiliated (and very likely frightened) to discover that a man had been secretly filming her while she changed her clothes in her bedroom. The one argument that the defendant might have made is that a reasonable person would not have anticipated that the plaintiff would be offended or humiliated by the filming because the expectation was that she would never find out about it. On its face, this argument may seem reasonable, as one normally cannot feel harassed without some awareness of the relevant conduct. However, a similar argument was rejected in the American case of Liberti v. Walt Disney World, ${ }^{48}$ one of the few reported decisions on secret videotaping as a form of sexual harassment. In that case, a male employee had drilled holes in the walls of the female dancers' dressing area and videotaped them in various states of undress. The defendant argued (in a motion for summary judgment) that the plaintiffs could not have perceived a hostile environment, as they were unaware of the videotaping until after it stopped. The court rejected this argument and held that the plaintiffs' after-the-fact knowledge could serve as the basis for their perception that a hostile work environment existed. In my view, the same principle should be applied to the reasonable person test in Yuen Sha Sha, as the statute does not require that a reasonable person would anticipate that the plaintiff would feel offended, humiliated, or intimidated while the acts were actually ongoing.

Yuen Sha Sha established an important precedent, one that has already been relied upon by other women who were the targets of voyeuristic behaviour. ${ }^{49}$ Unfortunately, the case also demonstrated how difficult it is to litigate a claim for sexual harassment and how meagre the compensation is likely to be. The plaintiff waited two 
years for her remedy and was harassed further by the defendant while the case was pending. During the trial she had to testify, relive the harassment, and suffer the embarrassment of further press coverage. At the end of this process, she obtained only HK $\$ 80,000$ (about US $\$ 10,000$ ) in damages plus a court-ordered apology. Such a small remedy may discourage others from litigating, particularly if they have to pay their own legal expenses. This issue is explored further in the next section of the article, on remedies and costs of litigation.

\section{REMEDIES FOR SEXUAL HARASSMENT AND COSTS OF LITIGATION}

Section 76 of the Sex Discrimination Ordinance sets forth the remedies that may be awarded for sex discrimination and sexual harassment. They can include: (i) damages (not only compensatory, but also punitive or exemplary damages); (ii) a declaration that the respondent has engaged in conduct that is unlawful, and that the respondent shall not repeat or continue such unlawful conduct; (iii) an order that the respondent employ or re-employ the complainant; and/or (iv) an order that the respondent shall perform any reasonable act or course of conduct to redress any loss or damage suffered by the claimant.

As originally enacted in 1995 , the Ordinance limited damages in any one action to a maximum of HK $\$ 150,000$ (less than US\$20,000). This limitation was not in the original Sex Discrimination Bill but was added at the time of enactment by an amendment proposed by a conservative legislator and supported by the government. However, the limitation was repealed (soon after the legislation came into force) by an amendment bill proposed by legislator Christine Loh. ${ }^{50}$ Ms Loh's bill (which also added the order to employ or reemploy the complainant to the list of available remedies) was strongly opposed by the government and the business community. Fortunately, her bill was voted on in June 1997, shortly before China resumed sovereignty over Hong Kong. On 1 July 1997, China replaced the elected legislature with an appointed a Provisional Legislative Council, which enacted a new election law and re-instated the system of small elitist functional constituencies (including corporate voting in some constituencies). This ensured that the business community would once again dominate the functional constituency seats, which make up 30 of the 60 seats in the Legislative Council and have a constitutional right to veto any bill that is not proposed by the government. ${ }^{51}$ Thus it would have been almost impossible to enact Ms Loh's amendment bill after 1 July 1997. 
Of course, the repeal of the limitation on damages will not make any difference unless Hong Kong judges are willing to make substantial damages awards. If a woman loses her job due to sexual harassment, the court can calculate damages based upon lost income. However, many sexual harassment cases (particularly those arising in areas other than employment) do not involve large economic losses but rather injury to feelings. In such cases, the damages awarded will depend greatly on the court's approach to assessing the impact of the harassment on the plaintiff. The initial cases indicate that Hong Kong courts will be quite conservative in their assessment of such damages.

For example, in the Yuen Sha Sha case (discussed above), the plaintiff was a full-time student. She missed classes as a result of the incident but still graduated with honours a few months later and obtained a position as a teacher by the time of the trial. Thus she did not claim any economic losses. ${ }^{52}$ Nonetheless, the incident caused her great distress. The Judge summarised the plaintiff's testimony as follows:

"... she was shocked, upset, distressed and literally trembling upon discovery of the camcorder. After viewing the tape in the camcorder, she was shaking and had to be supported by her friend ... the incident had left her feeling violated, exploited, betrayed, humiliated and hurt.... For sometime after the discovery, she was afraid to stay in her hostel room, and for the month following she was unable to go to sleep alone, and she did not attend class for 2-3 weeks. She felt she was watched whenever she changed her clothes." 53

It is clear that the judge recognised that the plaintiff was not just offended by the harassment. It left her in fear, caused her to lose weight, and interfered with her quality of life for a significant period of time. However, the judge assessed these damages at only HK $\$ 50,000$ (approximately US\$6,250). In searching for comparable cases, the judge referred to one case of racial discrimination but also to several defamation cases. The rationale for considering defamation cases was apparently the theory that the plaintiff's reputation had been damaged. In my view this approach missed the real crux of the plaintiff's claim. It also led the court to expressly devalue the damages suffered by the plaintiff because she was 'a student and not, at the time, a person enjoying a reputation in the community'. ${ }^{54}$ The social status of the plaintiff should not have been considered relevant to the compensation she received for feelings of violation, fear and other emotional pain.

The court did, however, also award exemplary and aggravated damages (totalling $\$ 30,000$ ) and this part of the judgement reflects greater sensitivity to the feelings of the plaintiff and the violation 
of her dignity. ${ }^{55}$ The court expressly found that the defendant's acts were aggravated by his 'perverted lewdness' (demonstrated by the care he took in directing the lens to the plaintiff's dressing area), the fact that he filmed her over a period of months, showed the tape to his friend, and caused friends to harass the plaintiff after she filed her complaint. ${ }^{56}$ However, even with this additional sum for exemplary damages, the plaintiff still received a total of only HK $\$ 80,000$ (approximately US\$10,000).

It should be noted that low damage awards are particularly problematic in Hong Kong because the legislation provides that the court shall not normally award costs to the prevailing party. ${ }^{57}$ This rule (an exception to the normal principle in Hong Kong, which is that 'costs follow the event') was adopted to allow a plaintiff to sue without fear of being bankrupted by the defendant's legal costs. However, it also means that a successful plaintiff will not normally receive an order of costs and could actually lose money if the judge does not award substantial damages. If the current trend of small damage awards continues in Hong Kong victims of sexual harassment will be unlikely to sue unless they fall within the fairly small category of cases that receive free legal assistance from the Equal Opportunities Commission (as did the plaintiff in Yuen Sha Sha).

In addition to damages, plaintiffs often seek the remedy of a court-ordered apology in harassment cases. In the Yuen Sha Sha case the plaintiff requested a written apology and the Judge ordered the defendant to provide it. The Judge relied upon section $76(3 \mathrm{~A})(\mathrm{b})$ of the Ordinance, which provides for an 'order that the respondent shall perform any reasonable act or course of conduct to redress any loss or damage suffered by the claimant'. Similar language in Australian legislation has been used extensively by Australian courts and equal opportunities tribunals as the basis for orders to apologise. However, in Hong Kong the legality of such orders has been contested.

The debate on court-ordered apologies arose in the case of $M a$ Bik Yung v. Ko Chuen, ${ }^{58}$ Hong Kong's first litigated case of disability discrimination and harassment. The plaintiff, a paraplegic who had been treated extremely badly by a taxi driver, was awarded HK\$20,000 in damages. The Court also ordered the defendant to apologise for his conduct (relying upon language in the Disability Discrimination Ordinance that is virtually identical to a remedies provision in the Sex Discrimination Ordinance). ${ }^{59}$ However, the defendant (who disputed the plaintiff's testimony and was vehemently opposed to apologizing) appealed to the Court of Appeal. The Court upheld the District Court's findings of fact and the finding of disability harassment, but granted the appeal from 
the finding of disability discrimination (for reasons not relevant here). The Court of Appeal then also reduced the already small damages award to $\$ 10,000$ and granted the defendant's appeal from the order to apologise. Interestingly, the Court of Appeal did not strike down the order to apologise on the ground that it violated the defendant's freedom of conscience and expression, which is the strongest objection to court-ordered apologies. Rather, the Court simply concluded, in a very brief decision, that an involuntary apology would provide no redress to the plaintiff for disability harassment and was therefore not within the scope of remedies permitted under the Ordinance. This was a very strange conclusion, given that the plaintiff herself had asked the court to order an apology and was fully aware that the defendant would not provide it voluntarily. ${ }^{60}$

Fortunately, the Equal Opportunities Commission assisted the plaintiff to appeal this portion of the judgement. Although the appeal was not successful for this particular plaintiff, the judgement greatly improved the state of the law. The Court of Final Appeal rejected the arguments that an involuntary apology would not redress a plaintiff's injury and could never be a 'reasonable' order under the terms of the Ordinance. However, the Court of Final Appeal did give careful consideration to the free-speech concerns that were not addressed in the Court of Appeal's judgement and set a standard that makes it difficult to order a defendant to apologise if he is vehemently opposed to doing so. In essence, the Court of Final Appeal held that if an apology appears to be a reasonable and appropriate remedy in the circumstances of the case, then the trial court should first make a provisional order including the apology (together with any other remedies, such as damages). However, if the defendant then makes it clear that $\mathrm{s} /$ he is vehemently opposed to apologizing, then the trial court should consider alternative remedies, such as a 'substantial increase in the quantum of damages'. ${ }^{61}$ The Court of Final Appeal confirmed that the trial court does have the power to issue a final order to apologise against an unwilling defendant, but held that this should only be done in 'rare cases' with exceptional circumstances, which it did not find in the case of Ma Bik Yung. ${ }^{62}$

I am aware that some disability rights groups and also some women's organizations were unhappy with the decision, as they viewed orders to apologize as a very important remedy in the context of disability and sexual harassment. An increase in the amount of damages does not necessarily provide the same vindication as a public apology. However, in my view, the Court of Final Appeal was right to emphasize freedom of expression given that Hong Kong is now a Special Administrative Region of China and many 
people feel that freedom of expression is under threat. Of course, the Court of Final Appeal's approach will not work at all unless Hong Kong courts start ordering larger awards for injury to feelings. It is encouraging that the Court of Final Appeal criticized the low damages received by Miss Ma (although there was no appeal on the quantum). The Court noted that the original award of $\$ 20,000$ 'was not a generous award' and that the Court of Appeal's decision to halve it 'led to an award which is clearly on the low side, especially as the order to apologise was quashed. ${ }^{63}$ The Court of Final Appeal also stressed that it is important for the court to bear in mind that the remedies granted, including the quantum of damages, should ensure respect for the legislation and its purpose. ${ }^{64}$ Hopefully, this language will encourage the courts to make more generous awards in all discrimination and harassment cases.

\section{CONCILIATION AND THE ROLE OF THE EQUAL OPPORTUNITIES COMMISSION}

In the first year that the law was fully in force (1997), the Equal Opportunities Commission received only 18 complaints of sexual harassment. As the public became more aware of the law, the number of complaints steadily increased. The Commission received: 54 sexual harassment complaints in 1998, 66 in 1999, 93 in 2000, 99 in 2001, 79 in 2002 and 131 in 2003. Indeed, sexual harassment complaints generally make up the second-largest category of complaints received by the Commission under the Sex Discrimination Ordinance (surpassed only by complaints of pregnancy discrimination). ${ }^{65}$ Since a very tiny percentage of these complaints proceed to court, one cannot assess the impact of the law unless one examines the process of investigation and conciliation at the Commission. Thus, as part of a broader study on the enforcement of Hong Kong equal opportunities laws, my research assistant and I interviewed officers from the Commission, past complainants, and other individuals who had assisted complainants and respondents in the complaints process. ${ }^{66}$

We also analysed a random sample of complaint files, consisting of all complaints concluded by the Commission over a nine-month period. ${ }^{67}$ The total sample included 451 complaints filed under three ordinances. 188 of these complaints were filed under the Sex Discrimination Ordinance, of which 55 alleged sexual harassment. ${ }^{68}$ The table opposite shows the types of sexual harassment that were alleged in these 55 complaints.

The most commonly alleged behaviour was unwelcome oral statements. Complaints that included this type of harassment 
Type of harassment alleged in a random sample of 55 sexual harassment complaints

\begin{tabular}{lrr}
\hline Type of sexual harassment & $\mathrm{N}$ & $\%$ \\
\hline Unwelcome physical sexual advances & 8 & 14.5 \\
Unwelcome verbal sexual advances & 1 & 1.8 \\
Unwelcome requests for sexual favours & 4 & 7.3 \\
Unwelcome conduct of sexual nature (oral statements) & 21 & 38.2 \\
Unwelcome conduct of sexual nature (physical) & 8 & 14.5 \\
Unwelcome conduct of sexual nature (in written form) & 3 & 5.5 \\
Sexually hostile environment & 8 & 14.5 \\
Voyeuristic behaviour & 1 & 1.8 \\
Unwanted requests for dates & 2 & 3.6 \\
Employers' vicarious liability & 16 & 29.1 \\
Others & 4 & 7.3 \\
Total number of complaints & 55 & \\
\hline
\end{tabular}

Note: The percentage column represents the percentage of complaints in the sample that included an allegation of this type. As some complaints alleged more than one type of sexual harassment, the $\mathrm{N}$ column totals to more than 55 and the \% column totals to more than $100 \%$.

generally alleged that the respondent had used sexually explicit or offensive language. The next largest category was allegations based upon the vicarious liability of an employer for harassment by another employee. Our review of the complaint files showed that very few of the employers named as respondents in our sample had, at the time the discriminatory acts took place, a sexual harassment and/or equal employment opportunity policy in place or a person designated to handle such matters. Many complainants claimed to have made an internal complaint before approaching the Commission but said that their employer had taken no steps to deal with the matter. Some complainants also alleged that they were dismissed after they complained to their employers. It appears that many of these employers were unaware of their potential liability. This is consistent with a Commission survey of employees and owner/operators of Small and Medium Enterprises (SME) and of employees and employers of Medium to Large Enterprises (MLE), which found that only $30 \%$ of SME employers and $34 \%$ of MLE employers were aware that they could be held vicariously liable for discriminatory acts carried out by their employees in the workplace. ${ }^{69}$

Unwelcome physical sexual advances accounted for 8 of the sexual harassment allegations in our sample. Examples of the conduct alleged included leering and lewd gestures, unwelcome touching, indecent assault and forced or coerced sexual relations. Our sample also included eight additional allegations of unwelcome physical conduct that was sexual in nature but did not amount to an actual sexual advance. There were also eight allegations of a sexually 
hostile environment, including obscene jokes around the workplace and the display of sexist or other sexually offensive pictures.

In our sample, 18 of the 55 sexual harassment complaints $(33 \%)$ were discontinued. Most of these were discontinued because the complainant herself decided not to pursue the complaint. In a few cases, the Commission found the complaint to be lacking in substance. We did not find any evidence that the Commission discontinues complaints lightly. We also noted that the discontinuation rate for sexual harassment complaints was lower than the overall discontinuation rate in our sample, which was $45 \%$. (The discontinuation rate was particularly high in complaints alleging disability discrimination.)

In the first few years after it was established, the Commission tended to investigate every complaint unless it was discontinued at the intake stage. However, in 2001 after a six-month trial programme, the Commission adopted a policy of encouraging "early conciliation', before the investigation stage. If the parties do not agree to participate in early conciliation or fail to reach an agreement then the complaint will be investigated. Assuming that the complaint is not discontinued during or after the investigation stage the officer will then suggest that the parties participate in post-investigation conciliation. However, this does not necessarily mean that the two parties sit down together and discuss the complaint. In many cases (particularly those involving sexual harassment), the complainant does not wish to meet the respondent. In such situations, the conciliation officer serves as a sort of messenger between the two parties and the process becomes more like settlement negotiations than what people might commonly think of as conciliation.

Thirty-seven of the 55 sexual harassment complaints in our sample proceeded to some form of conciliation (either early conciliation or post-investigation conciliation). Thirty of these complaints were ultimately conciliated, while seven were deemed 'unsuccessful conciliation', generating an overall conciliation rate of $55 \%$ for sexual harassment complaints. This is significantly higher than the overall conciliation rate for our total sample of 451 complaints, which was only $35 \%$. In the other main categories the conciliation rates were: $37 \%$ (pregnancy discrimination), $40 \%$ (sex discrimination), and $26 \%$ (disability discrimination). ${ }^{70}$

It should be noted however, that the remedies obtained through conciliation in the sexual harassment complaints were often fairly meager and frequently did not include monetary compensation. Based upon our sample, it appears that a significant number of complainants alleging sexual harassment do not even ask for monetary compensation as a remedy or they give up this request during the negotiations. Instead, they obtain an apology, a promise to establish 
a sexual harassment policy in the workplace, or a promise to prevent harassment in the future. This may be one of the factors leading to a higher conciliation rate in sexual harassment cases. It is fairly painless for an employer to provide an apology, particularly if the apology is given in very general terms and in a confidential setting. It is also fairly easy to promise to establish a sexual harassment policy, especially as the Commission does not follow up to see whether the policy was implemented ${ }^{71}$ and the complainant herself will often have left the company by this time.

In order to obtain a 'user's perspective' of the Commission's complaints process, my research assistant and I also interviewed several past complainants and representatives of organizations who have assisted complainants. In this section of the article, I summarize the comments that are most relevant to sexual harassment complaints. ${ }^{72}$ It should be noted that while our sample of complaint files was entirely random, the interviewees were not chosen randomly. The past complainants we interviewed were largely located though contacts with women's support groups and these groups tend to be critical of the existing model. Nonetheless, we were struck by the consistency of the interviewees' comments and I believe that they do represent the experience of at least a significant group of sexual harassment complainants. Some of our interviewees from NGOs had assisted several complainants at the Commission and they illustrated their opinions with specific examples.

We expected the interviewees to complain about the remedies that are obtained in conciliation. However, only a few of the past complainants brought up this point. They did say that they found it very difficult to suggest a remedy and to calculate damages and they wished that the Commission officers would offer more help in this regard. A number of the interviewees also said that they preferred a detailed written apology to a monetary award. (This is consistent with our review of the files, in which many complainants did not ask for monetary compensation.) One interviewee who had counseled a number of women in sexual harassment cases told us that Hong Kong women find it very offensive to be asked by the Commission officer to suggest an amount of monetary compensation - to the victim it seems as though she is being asked to sell her body or her dignity to the respondent. When we discussed this point with other NGO representatives, they agreed and added that they also find it offensive to hear that a respondent has offered a victim of sexual harassment a very small amount of money, often less than Hong Kong \$5,000 (about US \$640). They feel that these respondents are just insulting the complainant again, by suggesting that they can easily buy the right to touch or speak to her in an sexual manner. Our interviewees also noted (and our review of the files in 
our sample confirmed) that some of the 'apologies' obtained in conciliation are extremely vague. For many complainants, it is important that the respondent acknowledge that what he did constituted sexual harassment. However, respondents are often unwilling to do this (even though they cannot be sued once the complaint is conciliated) and will only agree to give a very general apology.

However, most of the negative comments from our interviewees concerned the process of investigation and conciliation rather than the actual settlement terms. Virtually all of our interviewees from the complainants' side commented that the Commission's role in the process is much different to what they had expected. Since the Commission was given a statutory power to investigate complaints, they had initially assumed that the officer would approach a complaint in much the same way that a police officer would investigate a complaint under the criminal law. They had expected the officer to actively gather evidence, contact and interview witnesses, and draft witness statements - all with the purpose of building a case against the respondent. As one woman who had filed a complaint of sexual harassment commented: 'I thought the Commission was an organization similar to the Police. I was the victim in this incident and was humiliated and treated unfairly. I thought when I lodged a complaint to the Commission they would investigate and prosecute the offender.' These women were surprised to find that the officer expected the complainant to provide so much in the way of information, documents, and witnesses. The interviewees described the officers as 'passive' and said that officers could do much more to investigate the complaint. Some past-complainants offered a different view, describing the officer in their case as helpful and hard-working. However, even those interviewees were disappointed at how little power the officer had. They claimed that the respondents would stall for time during the investigation stage and did not seem afraid of the officer's threats.

Virtually all the interviewees also commented negatively on the neutrality of the complaints officers (our interviewees generally used the term 'neutral' rather than 'impartial'). The officer can assist the complainant to draft her complaint letter but otherwise must be impartial towards the complaint. This duty of impartiality has proved extremely controversial among complainants and women's organizations, as they had expected the Commission to play more of an advocacy role. Our interviewees reported that the officers frequently mentioned their duty to be neutral. For example, a number of our interviewees described how the respondent would send very complicated letters, setting forth legal arguments against the complaint. The complainants are often baffled by these letters and have no idea what to say when asked to respond. According 
to our interviewees, if a complainant asks for help in digesting or responding to a letter from the respondent's lawyer, the officer is unlikely to give much advice, citing the duty of neutrality. My interviews with the officers themselves also indicate that they are very concerned about being accused of bias. Several officers mentioned that respondents will complain if the officer appears to be advising the complainant, arguing on her behalf, or suggesting that a settlement offer is on the low side.

Of course, from the point of view of our interviewees, a neutral officer simply does not fulfil the original mission of the Commission. Most complaints arise from an employment dispute and the complainant typically has to conciliate with a person who has far more socio-economic power than the complainant. If the respondent is an individual he was probably her boss or occupied a superior rank in the company. If the respondent is her employer (named by virtue of its vicarious liability) then it will be represented in the conference by a lawyer, a human resource expert, or some other managerial level employee. The complainant may be accompanied by a friend or a representative of a women's organization or a trade union. However, the extent to which this can address the power imbalance depends upon the relative expertise of the person accompanying the complainant when compared to that of the respondent. Although some of the $\mathrm{NGO}$ representatives that we interviewed were clearly very experienced and knowledgeable, they are not trained lawyers and cannot be expected to advise a complainant if the respondent makes complicated legal arguments. These organizations also operate on limited budgets and with limited staff.

Our interviewees also reported that the complainant generally can only bring a friend or NGO representative into the conciliation conference if the respondent also sends two people or gives permission for the complainant to have an extra person on her side of the table. Even then, our interviewees claimed that the supporter could not speak during the conference without permission. One representative of a women's group described how she had to sit outside the conciliation room, although the complainant, who had alleged sexual harassment, was clearly in distress and was actually in tears at the thought of going into the room on her own. The respondent would not give permission for her supporter to enter the room, taking the position that it would be 'unbalanced' because the respondent had only sent one person.

While on the face of it these rules may seem fair, they reflect a very literal understanding of what 'balanced' means and do not take into account the imbalance of power that often exists between the two parties. If the one person that the respondent sends is a 
lawyer or a highly experienced human resource manager, then a former clerical worker will clearly be at a disadvantage if she is on her own. The complainant may also be suffering emotionally from the harassment that led to the complaint. The past complainants who we interviewed frequently mentioned the emotional pain they suffered as a result of the harassment and the resulting dispute with their employer or former employer. They also talked at length about the stress and anxiety that they suffered during the investigation stage and noted that the Commission officers were not equipped to deal with emotional distress. A representative of a support group for victims of sexual violence told us that the Commission officers now regularly refer victims of sexual harassment to her for counseling, which is certainly a good thing. However, she also commented that the complaints process inevitably works 'to increase the complainant's suffering', as the complainant is required to relive the experience at every stage. Under these circumstances, it is important that the complainant always be permitted to bring her supporter into the conciliation conference - especially since the Commission's conciliation officers feel obligated to play a strictly neutral role in the conference.

Several of our interviewees also expressed disappointment at the fact that conciliation does not include a judgment by the Commission or by some other body. Many interviewees commented that complainants in sexual harassment cases come to the Commission in search of 'justice' and they are disappointed to find that no authoritative body will 'rule' on their complaint. As one representative of a women's group commented, 'why should the complainant answer all these questions and produce all the evidence if the result of the investigation is just a conciliation conference where the respondent can refuse to admit to anything?' Many of our interviewees said that they wanted the respondent to be prevented from committing the same act again and that they feared that a confidential settlement would not have that effect.

Confidential settlements also do little to raise public awareness of the problem of sexual harassment. The Commission does publish the results of some noteworthy conciliated cases in its Newsletter and in a new on-line settlement register, but always with the names and details changed to preserve confidentiality. Clearly these summaries do not generate nearly as much public attention as an actual court case. Moreover, one of our interviewees (an NGO representative who has assisted a number of women in sexual harassment complaints) argued that a settlement register without names actually sends out the wrong message - that a respondent can 'buy his way out' of a complaint for a fairly small sum of money and no damage to his reputation. 
It is often assumed that Hong Kong victims of sexual harassment would be too embarrassed to litigate their complaints. Our interviews with officers at the Commission confirm that a significant percentage of victims do value the confidential nature of conciliation and would not be willing to litigate their claims in a public forum, even if legal assistance were provided. However, many of the past complainants that we interviewed stated that they would be willing to litigate if they could afford to do so or were given legal assistance. Some of them expressly stated that they would prefer this to what they consider to be the greater indignity of being asked to negotiate with the person who harassed them. A representative of an organization that regularly assists sexual harassment complainants commented as follows:

"Some complainants do not want to conciliate with the respondent,
especially in the sexual harassment cases. They lodge the complaint
not because of wanting the respondent's money. They want to put
the case to court. They want society to know what the respondent
has done. In fact, when complainants come to lodge the complaints,
they are prepared to expose their cases. But in the current complaint
procedure, complainants are not given a choice. They are only
asked to go for conciliation and set an amount of monetary compen-
sation. It actually hurts their feelings."

An individual complainant who had alleged sexual harassment in employment expressed similar views. Her comments were particularly striking because her complaint was successfully conciliated and she received substantial monetary compensation (significantly more than the plaintiff received in the litigated case discussed earlier in this article). Nonetheless, she was bitter about the overall experience. She claimed that she felt "pushed to settle the case by the conciliation officer and also by [the respondent's] lawyer'. She also recalled how angry she was to find that conciliation was the next step after the lengthy investigation and she felt that it was a "waste of time to make all the effort to find the evidence in the investigation period.' In fact, her efforts almost certainly were not wasted because the evidence she put forward probably helped to persuade the lawyer to recommend a substantial settlement offer and her compensation was well above the average in conciliated complaints. However, from the complainant's perspective, the process felt like a waste of time because there was no judgment at the end and little sense of vindication.

Of course, if the conciliation does not lead to an agreement then the complainants will be even more disappointed with the process. Even if the evidence is strong the Commission cannot compel the respondent to participate in conciliation or to make a reasonable 
offer. One past complainant told us that she filed a complaint together with several other women, all alleging that they had been harassed by the same supervisor in their office. They brought complaints against both the supervisor and the company. The interviewee told us that the company offered some compensation and also agreed to establish a sexual harassment policy. However, she claimed that the individual respondent was very skillful at delaying the process, refusing to reply to the Commission and not showing up for conciliation meetings. She told us that at the end of a very long process he offered a small amount of money to each complainant and that all but one of the complainants refused his offer because they felt insulted by the low amount and by his dismissive attitude. They felt that the process had done nothing to change his behaviour or his attitudes toward women.

One of the points brought out in these interviews is the difference in the bargaining positions of the two parties, which is exacerbated by the uncertainty of obtaining legal assistance. Both parties know that if conciliation fails then the complainant must either abandon the claim or commence an action in the District Court. The complainant can apply for legal assistance but the Commission is not obligated to provide it (and the government's Legal Aid Department is unlikely to aid a complainant under the three antidiscrimination ordinances). In fact, a brochure given to both parties states that legal assistance generally will be granted only if the case 'raises a question of principle; or it is unreasonable, because of the complexity of the case or the applicant's position in relation to the respondent, to expect the applicant to deal with the case unaided'. 73 Thus, the complainant knows that if she declines an offer from the respondent she is running a risk of obtaining no remedy at all, despite the effort she has put into the process. She is therefore under some pressure to accept any offer. The conciliation officer may also subtly suggest that she accept the offer, not only to increase the officer's conciliation rate but also because the officer will feel badly if the complainant walks away with nothing. In contrast, the respondent is in exactly the opposite position. The respondent can offer a very low remedy, knowing that the complainant almost certainly cannot afford to sue without first applying for legal assistance. If the complainant accepts the low offer then the complaint is resolved. If the complainant rejects the offer and later obtains legal assistance, the respondent can offer to settle the case at that point and still avoid a public trial.

At the conclusion of interviews, we asked our interviewees whether they would support the establishment of an informal equal opportunities tribunal. The interviewees from the complainants' side generally supported establishing a tribunal, provided that 
it was inexpensive, reasonably informal, and staffed by members with gender awareness and expertise in the field. It was important to them that complainants be allowed to file a complaint directly in a tribunal, without first participating in mandatory conciliation. As a matter of principle, they felt that complainants should always be given the choice as to whether to participate in pre-hearing conciliation. They also noted that a long process of investigation and conciliation 'wears people down' and that some complainants might lose their energy and never go to the tribunal if they were forced to go through conciliation first. Of course, even if conciliation were not required the respondent could still offer to settle the case before the tribunal hearing and in practice many complainants might agree to settle if the terms were reasonable. Most of our interviewees also thought that the existence of a tribunal would make conciliation and pre-hearing settlement discussions more productive. They felt that respondents would have a greater incentive to conciliate the case if they knew that the complainant could go to a tribunal, with or without legal assistance from the Commission.

It should be noted, however, that some of the comments made by past complainants during our interviews do reflect a lack of understanding of the alternatives to the current model. For example, some interviewees said they would prefer litigation in court because it would be quicker than investigation and conciliation. This is almost certainly not the case, since litigation is generally extremely slow, although an informal tribunal should work faster than formal litigation in the District Court. It is also likely that some of our interviewees do not fully appreciate how stressful a trial or a hearing before a tribunal could be. Moreover, anyone who is employed (or hopes to be employed) may have second thoughts about a public hearing since Hong Kong is a small territory and employers are loath to hire anyone who has sued their employer in the past. Thus, I have no doubt that a certain percentage of complainants would continue to choose the confidential conciliation process even if a tribunal were created. However, the interviews reveal that a significant percentage of people would like to have the option to go directly to a hearing. Under the current system the complainant feels that she is being forced to compromise on her principles because she does not have the money to litigate on her own and because the Commission will not even consider her application for legal assistance unless she has already made a good faith effort to conciliate. This is not the fault of the Commission as it is only following its statutory duty to attempt conciliation. But the result is that a significant group of complainants and activists feel disempowered by the very organization that was supposed to empower them. 
Of course, the views expressed by the past complainants and women's support groups arguably express a one-sided view of the process. Unfortunately, we were only able to locate one individual respondent in a sexual harassment case who was willing to be interviewed about his experiences with the Commission's complaints procedures. He maintained that the allegations against him were entirely false and that the complainant was trying to get revenge against him for giving her a low grade in a performance appraisal. He also described the Commission's investigation process as very stressful and burdensome, saying that he was afraid to open the mail for fear that he would find another letter from the Commission asking him more questions. He told us that the stress became so great that his company referred him to a counselor and a member of his family introduced him to a friend who was a lawyer. Interestingly, this respondent recalled that: 'my lawyer said to me that I could ignore the Commission because it could not do much'. In the end he must not have felt too intimidated by the Commission, or else he felt very sure of his position, because he refused to conciliate the complaint. However, there is no question that the complaint did cause him considerable emotional distress. This is worth bearing in mind, particularly when considering the complainants' argument that the conciliation officer should assist the complainant in a more active manner.

Most of our interviewees from the respondents' perspective were not individual respondents but people who had represented their employer or their client at the Commission. A few were lawyers but most were human resource managers or other managerial-level employees of the respondent. All of the respondents' representatives that we interviewed were confident, articulate, and quite knowledgeable about the law, particularly as it affected their work. In general, the respondents' representatives were far more positive about the role of the Commission and the approach taken by officers than our interviewees on the complainants' side. Several of the interviewees from the respondents' side described the officers as playing a proactive role in the resolution of complaints, particularly during the conciliation conferences.

At first, it seems perplexing that the respondents' representatives view the Commission officers as being proactive while the complainants and their representatives view them as being so passive. However, this may be explained by the very different desires and expectations of the two groups. As demonstrated by our interviews, many complainants resent what is effectively, for them, a duty to participate in conciliation and they would not necessarily view active encouragement to conciliate as a positive thing. Complainants also expect the officers to be on their side and are disappointed when 
the officer insists upon playing a neutral role. In contrast, it was clear from our interviews with respondents' representatives that they had never expected the Commission officer to assist them and they were pleased to find that the officers were impartial and not biased against them.

Virtually all of the interviewees from the respondents' side said that they would probably oppose the creation of an equal opportunities tribunal. When asked why, one interviewee (a representative of a university) noted that conciliation offers the respondent a chance to learn from the experience, without the hostility of litigation. She felt that she and other senior administrators had learned a good deal from attending a conciliation conference and listening to a student describe her dissatisfaction with the complaints procedure at her university. However, most of the interviewees said that they would oppose the creation of a tribunal simply because it would make it too easy for complainants to bring weak cases to a hearing, wasting time and damaging the reputation of the respondent. In general, our interviewees from the respondents' side felt that a large percentage of complaints made under the three ordinances are weak and that respondents only conciliate them in order to save time. Some of the interviewees commented that sexual harassment complainants, in particular, often amount to nothing more than 'trivial comments' to which the complainant has over-reacted. Of course, this gap in perceptions is not confined to Hong Kong. The law and practice of sexual harassment is full of examples in which the complainant's and the respondent's view of what a 'reasonable person' would find offensive are hugely different.

\section{CONCLUSIONS AND THE WAY FORWARD}

The results of our interviews and review of the case files were presented at a conference in Hong Kong in 2003, which a number of officers from the Commission attended. ${ }^{74}$ To its credit, the Commission has already taken some steps to address concerns expressed by past-complainants and representatives of women's support groups. In particular, the Commission developed its on-line settlement register in 2003, which is designed to provide more transparency and publicity for the conciliated cases. Anna $\mathrm{Wu}$, the Chairperson of the Commission at the time of the conference, also stated that she hoped to provide more training to outside advocates (representatives of trade unions and women's support groups) and to encourage more private lawyers to offer pro-bono legal services for meritorious cases. ${ }^{75}$ 
The Commission is also studying the concept of an informal tribunal (or a simplified procedure in the District Court) in order to allow more complainants in equal opportunities cases to commence litigation on their own. The Commission itself cannot establish such a tribunal but it is actively studying the options, in order to make an informed recommendation to the government. There are many issues to consider, including whether to allow legal representation and whether tribunal hearings should be open to the public. More complainants would be willing to file complaints with a tribunal if their privacy could be preserved. The business community may also prefer confidential proceedings and its support is generally essential to any legislative proposals. However, public hearings would certainly do more to raise awareness of discrimination and harassment, which is a major concern of women's organizations and also the disability rights movement. The government has also now agreed to introduce a race discrimination bill (probably in 2005) and it will likely follow whatever enforcement model is used for the existing anti-discrimination ordinances. Thus, groups that are active in the racial equality movement should also be consulted on the procedures for any new tribunal.

Despite the difficulties in enforcement that have been identified in this article, there is no question in my mind that the sexual harassment provisions of the Sex Discrimination Ordinance have had a positive impact in Hong Kong. The existence of the legislation, backed up by the Commission's services, has encouraged women to come forward with complaints. It has also led numerous companies, universities, and other institutions to adopt and enforce explicit policies against sexual harassment - something that never would have occurred had it not been for the fear of vicarious liability. In some cases, administrators have been criticized for their initial ineptitude (or unwillingness) to effectively enforce these policies. For example, my own institution, the University of Hong Kong, received severe criticism from students and staff for the way that it addressed the well-publicized 'email case' ${ }^{76}$ However, the University responded by agreeing to review the procedures and by appointing a full-time Equal Opportunities Officer - something that students and staff had long lobbied for but was previously considered an unnecessary expense. The Equal Opportunities Officer now regularly conducts training sessions for staff who are designated to receive complaints in each department. There is also a good deal of promotional and educational material on campus on sexual harassment. I now regularly receive inquiries from students and staff about behaviour that they believe might contravene the Ordinance or the University's sexual harassment policy. These developments tell me that the community is becoming less tolerant of sexual harassment 
and more willing to take a stand against it. The Sex Discrimination Ordinance and the Equal Opportunities Commission are playing an important role in that process.

\section{NOTES}

* Associate Professor, University of Hong Kong. This article is part of a broader research project on the enforcement of equality rights in Hong Kong, entitled Enforcing Equal Opportunities In Hong Kong: A Study of Investigation, Conciliation, and Other Enforcement Mechanisms, supported by a grant from the Hong Kong Research Grants Council (RGC Reference HKU 7721/00H). Thanks are also due to Ms Janice Fong, Ms Gabriella Rush, and Ms Lison Harris, who assisted with the research for this article, to staff at the Hong Kong Equal Opportunities Commission and others who agreed to be interviewed, and to Prof. Andrew Byrnes and Dr Phillip Tahmindjis for their comments on a previous draft of this article.

1 Information provided by the Hong Kong Equal Opportunities Commission. See also Stella Lee, 'Alarm as sex bias cases rise by $78 \mathrm{pc}$ ', South China Morning Post, 1 February 2000, p. 1.

2 Cap. 480, Laws of Hong Kong (also available on the Web Site of the Hong Kong Equal Opportunities Commission: htpp:(/www.eoc.org.hk).

3 [1999] 1 HKC 731.

4 See Harriet Samuels, "Women and the Law in Hong Kong: A Feminist Analysis', in Raymond Wacks, ed., Hong Kong, China and 1997: Essays in Legal Theory (Hong Kong University Press 1993); and Carole J. Petersen, 'Equality as a Human Right: The Development of Anti-Discrimination Law in Hong Kong' (1996) 34 Columbia Journal of Transnational Law 335.

5 See Carole Petersen and Harriet Samuels, 'The International Convention on the Elimination of All Forms of Discrimination Against Women: A Comparison of Its Implementation and the Role of Non-Governmental Organisations in the United Kingdom and Hong Kong', (2002) 26 Hasting International and Comparative Law Review 1. See also Andrew Byrnes and Johannes Chan, eds, Public Law and Human Rights: A Hong Kong Sourcebook (Butterworths 1993), p. 298.

6 For a more detailed discussion of these and other examples of sex discrimination in Hong Kong during this period, see Petersen, 'Equality as a Human Right', note 4 above.

7 For a more detailed discussion of these developments and their impact on equality rights, see Petersen, note 4 above, especially pp. 348-86.

8 Equal Opportunities Bill 1994, Hong Kong Government Gazette, Legal Supplement No 3, 1 July 1994, pp. C991-C1275.

9 See, for example, Strathclyde Regional Council v. Porcelli [1986] IRLR 134 CS (holding that sexual harassment can constitute discrimination within the meaning of the UK Sex Discrimination Act 1975). 
10 The main advantage to this approach is that the victim need not prove that the harassment was discriminatory. For example, in the UK case of Stewart Cleveland Guest Engineering Ltd [1994] IRLR 440, the Employment Appeal Tribunal upheld a decision that pictures of nude women did not constitute sex discrimination under the UK Sex Discrimination Act 1975 because a man might have found the pictures equally offensive. However, under the Hong Kong Sex Discrimination Ordinance, this would be irrelevant, as the plaintiff would not be required to show that the harassment was discriminatory but rather that it met the statutory definition of prohibited sexual harassment.

11 Wu had also drafted a Human Rights and Equal Opportunities Commission Bill, but the Governor used his power under Article XXIV of the Royal Instructions to prevent her from introducing it into the legislature. See Petersen, note 4 above, at pp. 372-6 for further discussion of this issue. The draft bill was published in George Edwards \& Andrew Byrnes, eds, Hong Kong Bill of Rights: 1991 and Beyond (Faculty of Law, University of Hong Kong 1995), at Appendix.

12 For further discussion of the drafting of the sexual harassment provisions, see Harriet Samuels, 'Upholding the Dignity of Hong Kong Women: Legal Responses to Sexual Harassment' (1995) 4 Asia Pacific Law Review 90.

13 Ng Sek-hong, 'Employment and Human Rights in Hong Kong' (1994) 24 Hong Kong Law Journal 108, at 124-5.

14 The Green Paper on Equal Opportunities for Women and Men (1993) was issued by the Hong Kong government primarily as a way of delaying a more definitive response to a motion passed by the Legislative Council in December 1992 calling for the extension of CEDAW to Hong Kong. Although officially a consultation document, the government did its best in the Green Paper to portray sex discrimination as an insignificant problem, which did not require legislation. At the conclusion of the document (at paras 137-40), the government discussed the possibility of adopting a non-enforceable charter of rights for women. However, the majority of public submissions supported the enactment of enforceable legislation, as well as the extension of CEDAW to Hong Kong. For more discussion of the Green Paper exercise, see Petersen, Equality as a Human Right, note 4 above, at 366-8.

15 There was also some initial discussion of assigning employment discrimination cases to the Labour Tribunal, an idea that might have appealed to employers but probably not to employees and NGOs (as the Labour Tribunal is perceived by many NGOs as being too proemployer).

16 Applying the definition of sexual harassment provided in section 2(5)(a)(ii) (discussed below), such comments could be considered unwelcome sexual conduct (which is expressly defined in section 2(7) to include a written or oral 'statement of a sexual nature'). The question then would be whether the statements were such that a reasonable person would anticipate that they would cause the gay employee to be 'offended, humiliated, or intimidated.' 
17 For a discussion of the attempt to enact legislation prohibiting discrimination on the ground of sexuality, see Carole Petersen, 'Values in Transition: the Development of the Gay and Lesbian Rights Movement in Hong Kong' (1997) 19 Loyola of Los Angeles International and Comparative Law Journal 337.

18 Section 76(1) (which addresses claims under Parts III and IV of the Ordinance) has introduced some unnecessary confusion on this point. Section 76(1) lists several situations in which the employer is liable for acts of discrimination by virtue of section 46, but does not mention vicarious liability for acts of harassment. Thus, it is arguable that although vicarious liability is clearly established in section 46 for unlawful acts of sexual harassment, a remedy is not obtainable under section 76. However, in my view the Ordinance should not be interpreted this way. Rather, section $76(1)(\mathrm{c})$ should be interpreted as allowing a claim for sexual harassment either against the actual harasser or against his employer. This is because, for the purposes of the Ordinance, the employer itself 'commits' any acts of harassment that occur in the course of the harasser's employment (pursuant to section $46(1)$ ).

19 Sex Discrimination Ordinance, section 46(3).

20 Ibid, section 69(14).

21 Chen v. Rus and IBM (HK) Limited, DCEO 2/99 (District Court, 6 April 2000), p. 51. (A subsequent appeal by the plaintiff was denied by the Court of Appeal at [2002] 1 HKC 545.)

22 See Chang Ying Kwan v. Wyeth (HK) Ltd. [2000] 2 HKC 129. While still employed by the defendant, the plaintiff telephoned the Hong Kong Equal Opportunities Commission to obtain advice about a possible pregnancy discrimination complaint. She was subsequently treated badly by her supervisor, in part because of her complaint. The woman later obtained legal assistance from the Commission and successfully sued the company for pregnancy discrimination and also for victimization under section 9.

23 Sex Discrimination Ordinance, section 9(2).

24 Chen v. Rus and IBM (HK) Limited, note 21 above, pp. 23-4 and 50.

25 Ibid, p. 50.

26 Ibid, p. 24.

27 Ibid, p. 25.

28 Section 2(6) states: 'For the avoidance of doubt, it is hereby declared that paragraph (b) of subsection (5) shall not apply for the purpose of sections 39 and 40.' Sections 39 and 40 generally apply to nonwork related areas. Unfortunately, harassment against barristers and their pupils was for some reason placed in section 40, meaning that the potentially broader definition of hostile environment harassment cannot be used in such cases, although a barrister's chambers is clearly a place of work (and a secretary working in the chambers could use the definition in section $2(5)$ (b) as she is an employee and is covered by section 23). Although, as noted below, the difference between the two definitions may be of little consequence (depending on how the 
courts interpret 'in relation to'), this anomaly in the legislation should be amended.

29 Section 28(3) of the Australian federal Sex Discrimination Act originally provided that a person shall be taken to harass sexually another person if he "makes an unwelcome sexual advance, or an unwelcome request for sexual favours, to the other person or engages in other unwelcome conduct of a sexual nature in relation to the other person, and: (a) the other person has reasonable grounds for believing that a rejection of the advance, a refusal of the request or the taking of objection to the conduct would disadvantage the other person in any way in connection with the other person's employment or work or possible employment or possible work; or (b) as a result of the other person's rejection of the advance, refusal of the request or taking of objection to the conduct, the other person is disadvantaged in any way in connection with the other person's employment or work or possible employment or possible work.' This provision was repealed and replaced with section 28A (noted below) in 1992.

30 Section 28A of the Australian federal Sex Discrimination Act now provides that a person sexually harasses another person if: (a) the person makes an unwelcome sexual advance, or an unwelcome request for sexual favours, to the person harassed; or (b) engages in other unwelcome conduct of a sexual nature in relation to the person harassed; in circumstances in which a reasonable person, having regard to all the circumstances would have anticipated that the person harassed would be offended, humiliated or intimidated.

31 This was confirmed by Judge Wong in Chen $v$. Rus and IBM, note 21 above, p. 45

32 Ratcliffe v. Secretary for Civil Service \& Anor, [1999] 4 HKC 237, 250 (Hong Kong Court of Appeal).

33 The Equal Opportunities Commission has thus recommended that a version of the hostile environment definition of sexual harassment be extended to the field of education. See Equal Opportunities Commission, Equal Opportunities Legislative Review: Proposals for Amendment of the Sex Discrimination Ordinance and the Disability Discrimination Ordinance, February 1999, para 3(a).

34 The defendant's sentence was suspended on the condition that he would continue to receive regular psychiatric treatment (which he had commenced shortly after his arrest).

35 [1999] 1 HKC 731. Portions of my discussion of this case are condensed from my previous article, 'Implementing Equality: An Analysis of Two Recent Decisions Under Hong Kong's Anti-Discrimination Laws' (1999) 29 Hong Kong Law Journal 178, especially pp. 179-88.

36 [1999] 1 HKC 731, 736.

37 The defendant also admitted to a police officer that he had obtained the key to the room from his girlfriend (the plaintiff's roommate) and checked the plaintiff's lecture timetable so that he could install the camcorder while she was in class. Thus, although it is not necessary under the Ordinance to show that the defendant knew that his conduct 
was unwelcome, the care he took to conceal his conduct makes it clear that he did. Ibid.

38 Ibid, pp. 735-6. Although the defendant later denied saying this (in his written defence), he did not testify or introduce any evidence to contradict the plaintiff's testimony and the court thus found his denial to be unproven. Ibid, p. 738.

39 The defendant told the police that he filmed the plaintiff for fun and told the Privacy Commissioner that he did it so he and his friend could watch the video together. Ibid, p. 744.

40 See Strathclyde Regional Council v. Porcelli [1986] IRLR 134 CS (in which the defendants embarked upon a campaign of sexual harassment to compel the plaintiff to quit or apply for a transfer).

41 See $R v$. Court [1988] 2 All ER 221, in which the House of Lords stated that certain acts (such as removing a woman's clothes without her consent) are unambiguously indecent, regardless of whether the defendant acted out of sexual desire.

42 Ibid, p. 223 (per Lord Griffiths).

43 See, for example, Robinson v. Jacksonville Shipyards, Ind, 760 F Supp 1486 (MD Fla. 1990); Horne \& Anor v. Press Clough Joint Venture \& Anor (1994) EOC 92-556 (Western Australian Equal Opportunity Tribunal).

44 See, for example, Hall \& Ors v. A \& A Sheiban Pty Ltd \& Ors (1989) EOC 92-250, in which questions in pre-employment interviews (as to whether applicants were having sex with their boyfriends, using contraceptives, or had ever had an abortion) were held to constitute unlawful sexual harassment.

45 Insitu Cleaning Co. Ltd. v. Heads [1995] IRLR 4.

46 Ibid, p. 5.

47 For example, in Ellison v. Brady, 934 F.2d. 872, 878-81 (9th Cir. 1991), the trial court had held that love letters and persistent requests for dates were trivial and unlikely to intimidate. However, the appellate court disagreed and expressly adopted a reasonable woman standard for assessing whether conduct constituted unlawful harassment.

48912 F. Supp. 1494, 1504 (MD Fla. 1995) (denying defendant's motion for summary judgement). The case settled before trial.

49 I am aware of two subsequent cases in Hong Kong in which women filed complaints of sexual harassment based upon voyeuristic behaviour and received monetary compensation through the Equal Opportunities Commission's conciliation procedures. One of these cases (in which a woman discovered her employer peeking at her over a divider in the toilet) was featured in the Commission's quarterly publication EOC News (July 1999).

50 See Sex and Disability Discrimination (Miscellaneous Provisions) Ordinance, Ord. No. 71 of 1997, Hong Kong Government Gazette, Legal Supp. No. 1, Part I of II, 27 June 1997.

51 The Hong Kong Basic Law (Hong Kong's constitution as a Special Administrative Region of China) provides, at Annexe II, that a bill or amendment proposed by an individual legislator (as opposed to 
the government) will only pass if it receives a majority of votes from both groups of legislators: those elected by the functional constituencies and those elected by other methods. Thus a bill or amendment proposed by an individual legislator can be defeated by only 15 of the 60 votes, so long as those 15 nay votes are from the functional constituency representatives. This provision was added to the Basic Law to make it more difficult for legislation that is opposed by the government and the business community to be enacted.

52 [1999] 1 HKC 731, pp. 741 and 745.

53 Ibid, p. 737.

54 Ibid, p. 741.

55 Ibid, pp. 742-6.

56 The defendant's friend made harassing telephone calls to try to persuade the plaintiff to drop the claim and his girlfriend (the plaintiff's former roommate) actually sued Ms Yuen and her boyfriend in nuisance and for sexual harassment (claiming that Ms Yuen had allowed her boyfriend to stay overnight in their room). The nuisance action was dismissed for disclosing no cause of action and the application to add a claim for sexual harassment was dismissed on the ground that the defendant's girlfriend refused to plead that any particular sexual conduct ever took place while she was in the room. Both decisions were upheld by the Court of Appeal. See $\mathrm{Ng}$ Hoi Sze v. Yuen Sha Sha and Another [1999] 3 HKLRD 890. The Court of Appeal did note, however, that if a student was prepared to plead that some identified sexual conduct had occurred in her shared room, without her consent, this could be actionable as student-to-student sexual harassment.

57 See District Court Ordinance, sections $73 \mathrm{~B}$ and $73 \mathrm{C}$, which provide that in actions brought under the Sex Discrimination Ordinance and the Disability Discrimination Ordinance each party 'shall bear its own costs unless the Court orders otherwise on the ground that (a) the proceedings were brought maliciously or frivolously; or (b) there are special circumstances which warrant an award of costs. Interestingly, in Yuen Sha Sha the Judge did award costs (on the ground that the defendant had behaved outrageously, perhaps even maliciously, after the plaintiff filed her complaint). However, the award could not be enforced because the defendant had received legal aid and section $16 \mathrm{C}(1)$ of the Legal Aid Ordinance provides that where a court makes an award of costs against an aided person neither that person nor the Director of Legal Aid shall be liable for such costs unless the non-aided person was a defendant or respondent in the proceedings. Fortunately, the plaintiff had received legal assistance from the Equal Opportunities Commission.

58 Ma Bik Yung v. Ko Chuen [1999] 1 HKC 714 (District Court), [2000] 1 HKC 745 (Court of Appeal), and [2001] 4 HKC 119 (Court of Final Appeal).

59 Ma Bik Yung v. Ko Chuen [1999] 1 HKC 714, especially at 730.

60 For a criticism of the Court of Appeal's analysis on this point and a discussion of the free-speech objections to court-ordered apologies 
see Carole J. Petersen, 'The Failure of the Hong Kong Court of Appeal to Recognise and Remedy Disability Discrimination' (2000) 30 Hong Kong Law Journal 6, especially at 11-21.

61 Ma Bik Yung v. Ko Chuen [2001] 4 HKC 119, 132, emphasis added.

62 Ibid, at p. $135-7$

63 Ibid, at p. 139.

64 Ibid.

65 Information provided by the Hong Kong Equal Opportunities Commission. See also Stella Lee, 'Alarm as sex bias cases rise by $78 \mathrm{pc}$ ', South China Morning Post, 1 February 2000, p. 1. The distribution of complaints under the Sex Discrimination Ordinance has been fairly stable except for 2001, the year that EOC v. Director of Education [2001] 2 HKLRD 690 was decided, in which the court upheld the Commission's application for judicial review and issued a declaration that the government's system of allocating students to secondary school discriminated on the ground of sex. This led to a surge in the number of complaints of sex discrimination, as many students were not sure whether they had been disadvantaged by the system and wanted the Commission to investigate. See Samuels and Petersen, note 5 above, for discussion of this case and the court's reliance on CEDAW to interpret the Sex Discrimination Ordinance.

66 Several of the interviews were originally conducted in Cantonese and later translated into English, by Ms Janice Fong, former Senior Research Assistant at the Centre for Comparative and Public Law, University of Hong Kong.

67 The sample was defined as all complaints concluded by the Commission from 1 July 2000-31 March 2001. 188 of these complaints were filed under the Sex Discrimination Ordinance, 254 under the Disability Discrimination Ordinance, and 9 under the Family Status Discrimination Ordinance. For a full report on the statistical results of the study, see Carole J. Petersen, Janice Fong, and Gabrielle Rush, Enforcing Equal Opportunities: Investigation and Conciliation of Discrimination Complaints in Hong Kong (Centre for Comparative and Public Law, University of Hong Kong 2003).

68 The other complaints in the sample that were filed under the Sex Discrimination Ordinance alleged pregnancy discrimination (73); sex discrimination (43); marital status discrimination (7); and victimization (10).

69 Equal Opportunity in the Business Community: Survey on Employees and Owners/Operators of Small and Medium Enterprises (SME) and Survey on Employees and Employers of Medium to Large Enterprises (MLE), Equal Opportunities Commission 2002 (available at the EOC website: www.eoc.org.hk).

70 See note 67 above, at Table 23. Disability harassment had an overall conciliation rate of $49 \%$ but this was a fairly small category of complaints in our sample ( 39 total complaints, 19 of which were conciliated).

71 Interviews with Commission officers confirmed that the Commission does not have a policy of following up to see whether such promises are implemented. 
72 A more complete report of the interview results (which also included several individuals who had been involved in disability and pregnancy discrimination complaints), see Petersen, Fong, and Rush, note 67 above, Chapter Six.

73 See What is Conciliation?, at p. 7 (Hong Kong Equal Opportunities Commission).

74 See the conference papers presented at Enforcing Equal Opportunities in Hong Kong: An Evaluation of Conciliation and Other Enforcement Powers of the EOC, 14 June 2003 (available on the website of the Centre for Comparative and Public Law, University of Hong Kong: www.hku.hk/ccpl).

75 Anna Wu's contract was not renewed in July 2003. Many people believe that she was not renewed because she was too assertive in the post and had successfully sued government departments in two controversial cases. Ms Wu's immediate successor, retired judge Mr Michael Wong, resigned after only three months amid allegations that he improperly terminated the contract of an incoming director of operation. The Commission's reputation suffered considerable damage during this controversial period and it is unclear whether it will be as independent and assertive in future years. For a discussion of the controversy, see Carole J. Petersen, 'The Paris Principles and Human Rights Institutions: Is Hong Kong Slipping Further From the Mark?', (2003) 33 Hong Kong Law Journal 513.

76 During the 'email case' (discussed above), the University was criticized for failing to immediately advise the police when it had traced the source of the threatening emails. The University also refused (for more than one month) to advise the victim of the identity of the sender of the emails, even after he had sent her a death threat. 